\title{
The Role of Remittances on Economic Growth: An Empirical Investigation Of 12 CEE Countries
}

Altin Gjini, State University Aleksandër Moisiu, Albania

\begin{abstract}
This study investigates the role of remittances on economic growth in Central and Eastern European (CEE) countries. The main concern of CEE countries after the collapse of Communism has been to develop strategies for increasing their standard of living to the level of Western countries. Economic growth experienced after 1991 has been impressive for these countries. Factors that have influenced economic growth in developing countries vary from capital investment, to labor surplus, technological change, trade, foreign aid, foreign direct investment, research and development, and institutional factors. This paper's main objective is to examine the impact of remittances on economic growth in 12 CEE developing countries ${ }^{1}$ using balanced panel data covering the period from 1996-2010. We do this by using a fixed-effects model with heteroscedasticity corrected standard errors. We find that remittances have had negative effects on growth in this area for the period analyzed. Thus, an increase in remittances by $10 \%$ decreases the output by about $0.9 \%$.
\end{abstract}

Keywords: Remittances; Economic Growth; FDI; Capital Flow; Fixed Effect Model

\section{INTRODUCTION}

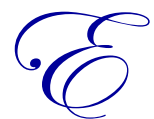

conomic growth is the main objective of developing countries as their way to bring their standard of living in line with developed countries. Sources of economic growth have been a main topic that economists have addressed for more than half a century. Other studies have examined factors such as capital, labor, technology, human capital, initial level of gross domestic product (GDP), foreign direct investment (FDI), remittances, official aid, economic freedom, and political stability. In this line of research, Solow (1956; 1957) concluded that an increase in capital and labor, along with technological change, positively affects economic growth. Denison (1980), in his work "The contribution of Capital to Economic growth," concluded that physical capital is one of several important sources of economic growth. Romer (1986) concluded that technological change has a positive effect on growth, and Barro (1991), after analyzing 98 countries, concluded that economic growth was positively related to human capital and political stability and negatively related to the initial level of real GDP per capita. Meanwhile, De Long and Summers (1991) and De long, Summers, and Abel (1992) found a strong association between investment in fixed capital (machinery and equipment) and economic growth, and Shujie Yao and Kailei Wei (2007) concluded that factors, such as labor input, use of capital, technological change, human capital, foreign aid, foreign direct investment, and investing in research and development (R\&D), have a positive effect on economic growth. After analyzing data on 100 countries for the period 1975 to 1992, authors Wu and Davis (1999) found economic freedom was a fundamental factor in fostering economic growth, with a high level of income being the condition for a high degree of political freedom. Finally, Scully (2002) concluded that economic freedom promoted economic growth.

On their way to fostering prosperity, developing countries are characterized by shortage of external capital flow, which is an important factor that promotes investment and accelerates economic growth. In addition to official

\footnotetext{
${ }^{1}$ Albania, Bulgaria, Croatia, Czech Republic, Hungary, Latvia, Lithuania, Macedonia, Poland, Romania, Slovakia, and Slovenia. 2013 The Clute Institute http://www.cluteinstitute.com/ 
development assistance, other official aids and foreign direct investment, remittances are considered an important way to increase the amount of foreign capital inflow. The World Bank (2011) concluded that the total amount of remittances received by developing countries in 2010 was about US $\$ 325$ billion, which is more than double the amount received in 2004 (US\$159 billion). Remittances offer additional advantages compared to other sources of financing. First, remittances are the second largest amount of foreign capital inflow after FDI, surpassing official development assistance and aid received, as well as other sources of external capital (World Bank, 2011). Second, remittances received by developing countries are stable. They have continued to increase each year, with the exception of a decrease in 2009 when the amount of remittances was US $\$ 307$ billion compared to US $\$ 325$ billion in 2008 (World Bank, 2011). Third, remittances are underestimated because the amount flowing reported does not consider transfers through informal channels (such as family and friends).

After the collapse of political and economic systems in CEE countries in 1991, the main objective of policy makers was to secure sustainable economic growth to increase the standard of living to the level of Western countries. Negative growth rates, high unemployment rates, high inflation rates, and pessimistic perspectives for a better life were characteristics of Eastern European countries during this time. With this prevailing pessimistic situation, about four million people emigrated from CEE countries to Western countries during the period 1989 to 1994 (Fassman \& Munz, 1994). The majority of people saw the immigration to Western European countries as a way to ameliorate their life and the lives of their relatives who remained in the home country. Since then, emigrants' remittances have poured toward home countries and have been considered a very important financial channel for increasing the amount of foreign capital.

The performance of CEE countries in achieving sustainable economic growth has been remarkable during the period under investigation. Still, not all countries have achieved the same level of income per capita. Based on World Bank classifications (2012), countries such as the Czech Republic, Hungary, Poland, Slovakia, Slovenia, and Croatia now belong to the group of countries with high income, whereas countries such as Albania, Bosnia Herzegovina, Bulgaria, Latvia, Lithuania, Macedonia, Montenegro, Romania, and Serbia are in the group of countries with upper-middle income. In the present paper, we have not accounted for the data on countries such as Bosnia Herzegovina, Montenegro, and Serbia because they have missing data for the period examined.

The main objective of the present paper is to highlight the impact of remittances on the economic growth of twelve CEE countries using balanced panel data spanning 1996 to 2010. Data are taken from the World Bank Indicators (2012). The empirical analysis uses fixed-effect models (regression with a mixture of quantitative and qualitative repressors). The present paper contributes to the empirical evidence by demonstrating the effect of remittances on the economic growth of recipient economies. This paper's empirical result is that remittances had a negative and statistically significant effect on the economic growth of CEE countries for the period under consideration. Also, the results reveal that the role of foreign direct investment on growth was negative and statistically significant. Furthermore, we found a positive and statistically significant role of other sources of financing such as investments in fixed capital and the openness of the economy in driving economic growth.

This paper is organized in five sections. In the second section, the literature review, we present several conclusions achieved in empirical studies regarding the role of remittances on growth in developing countries. The third section consists of stylized facts about the economic performance of the sample countries; data, definition, and descriptive statistics on each variable; and the methodology used for regression models. In the fourth section, we present our hypotheses and develop empirical models for testing them. The last section states our conclusions, which summarizes the study's results.

\section{LITERATURE REVIEW}

The role of workers' remittances on the economic growth of developing countries is generally accepted by policy makers as a very important economic factor. Remittances are very large in size, stable, and provide direct benefits to households. However, conclusions of empirical work about the effects of remittances on economic development for recipient countries vary. Some of them argue that remittances have positive effects on economic growth in developing countries, while others maintain that remittances have an insignificant impact on growth. Guliano \& Ruiz-Arranz (2009) in their work "Remittances, Financial Development and Growth," found that 
remittances promoted growth in financial markets that were relatively underdeveloped, which made the effect of remittances on growth conditional on the degree of financial development. Mundaca (2009) in her paper titled "Remittances, Financial Market Development, and Economic Growth: The Case of Latin America and the Caribbean," concluded that remittances have a significant positive effect on long-term growth. After analyzing data on 60 emerging and developing economies for the period 1980-2003, Bugamelli and Paterno (2011) in their work "Output Growth Volatility and Remittances" concluded that remittances have a positive impact on economic growth, whereas Miguel Leon_Ledesma and Matloob Piracha (2004) in their work "International Migration and the Role of Remittances in Eastern Europe" analyzed data on 11 CEE countries for the period 1990-1999 and concluded that remittances have a positive influence on economic growth. Finally, Bichaka Fayissa and Christian Nsiah (2010) analyzed the economies of 36 countries in Africa and concluded that remittances positively affect economic growth.

Other empirical works have found no direct impact of remittances on growth but only a small spillover effect. In this line of research, Bhaskara Rao and Gazi Mainul Hassan (2012) in their work "Are the Direct and Indirect Growth Effects of Remittances Significant?" analyzed 40 high remittance recipient countries and found that remittances have no direct growth effect, with the impact on growth being only small and indirect. Some authors have argued that remittance transfers between migrants and their relatives in their home countries are used mainly for consumption. At the same time, others have maintained that these remittances are used for investing in goods. For example, Koc and Onan (2004) and Russell (1992) concluded that recipients spend remittances for immediate consumption, whereas Taylor (1992) concluded that remittances were spent to acquire homes and land.

Furthermore, another line of empirical work concluded that remittances have, in fact, a negative effect on output growth. In this context, Chami, Fullenkamp, and Jahjah (2005) in their work "Are immigrant remittance flows a source of capital development" analyzed data for 113 countries over the period 1970-1998 and concluded that remittances have a negative impact on growth; likewise, Barajas et al. (2009) concluded that the growth effects of remittances are insignificant and at times even negative.

\section{STYLIZED FACTS, DATA, AND METHODOLOGY}

The main objective of the present paper is to analyze the effect of remittances on economic growth experienced in 12 CEE countries for the period 1996-2010. The countries analyzed cover a significant portion of CEE countries. One of the most remarkable results of these economies is the economic growth achieved during last two decades (Figure 1). Based on World Bank (2012) classifications, countries such as the Czech Republic, Hungary, Poland, the Slovakia, Slovenia, and Croatia are listed in the group of countries with high income, while countries such as Albania, Bulgaria, Latvia, Lithuania, Macedonia, and Romania are in the group of countries with upper-middle income. In the present paper, we use this classification to compare the impact of remittances on economic growth in the above-mentioned groupings of countries. 


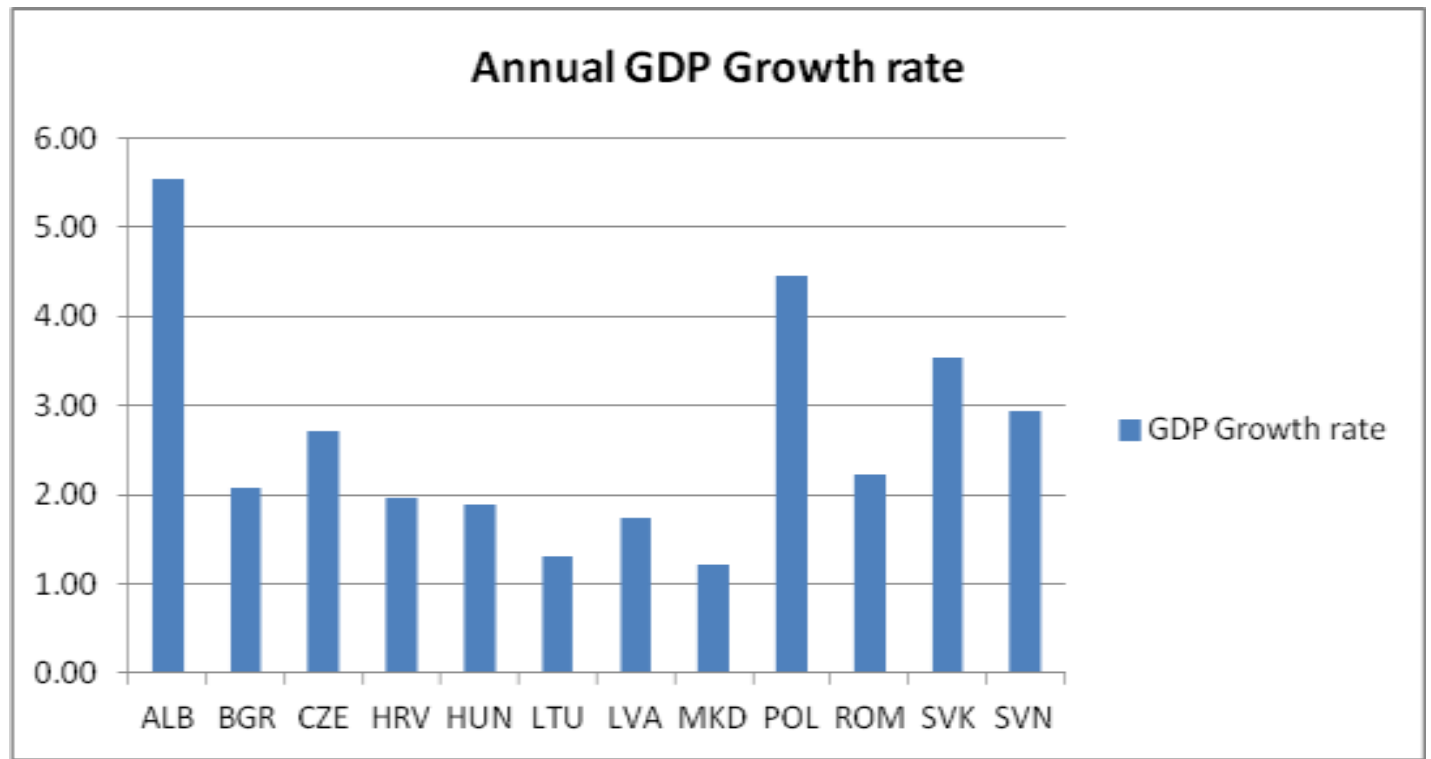

Figure 1: Annual GDP Growth Rate Averaged for Period 1992-2010²

The total amount of remittances received by CEE countries annually for the period of time 1996-2010 generally has increased from year to year. As shown in Figure 2, the total amount of remittances received was reduced in 1997, 1999, 2009, and 2010 compared to the respective previous years. For the period 2000-2008, however, the amount increased year after year. The total amount of remittances received in 2008 was 12 times more than the total amount received during 1996.

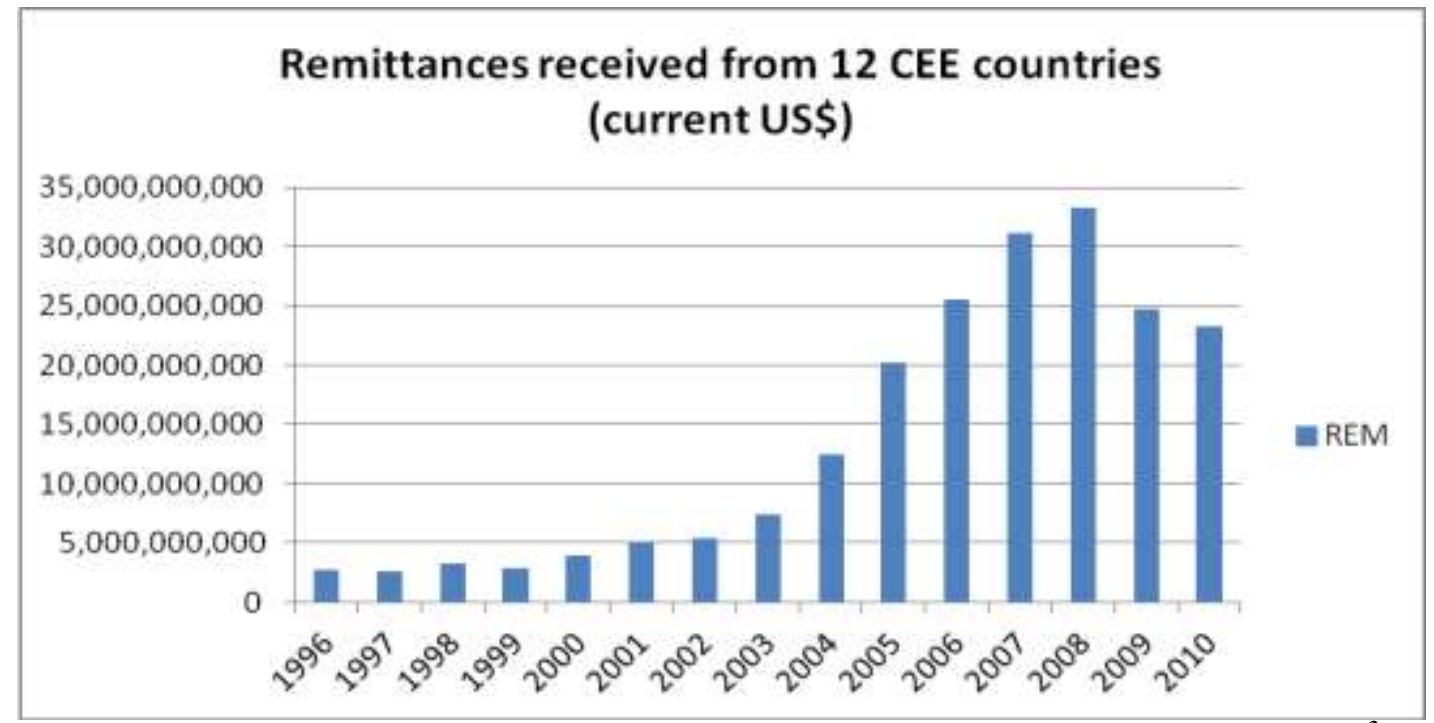

Figure 2: Total Annual Amount of Remittances Received by 12 CEE Countries Period 1996-2010 3

Besides remittances, other variables considered include gross fixed capital formation (GFC), foreign direct investment (FDI), and the openness of the economy (TOT). We have not taken as an explanatory variable net official development assistance and aid received because of missing data for the period under consideration. To study how these factors have influenced growth, we start with a simple double log-linear Cobb-Douglass production function as follows:

\footnotetext{
${ }^{2}$ World Development Indicators; Author's calculation.

${ }^{3}$ World Development Indicators; Author's calculation.
} 


$$
\ln g d p=\beta_{0}+\beta_{1} \ln r e m_{i t}+\beta_{2} \ln g c f_{i t}+\beta_{3} \ln f d i_{i t}+\beta_{4} \ln t o t_{i t}+\varepsilon_{i t}
$$

where,

ln gdp, is the natural log of real DGP per capita.

ln rem, is the natural log of Remittances per capital.

ln gcf, is the natural log of gross capital formation per capita.

$\ln \mathrm{fdi}$, is the natural log of foreign direct investment as percentage of GDP.

ln tot, is the natural log of terms of trade, to measure the effects of openness of economy.

The methodology used in the present paper is that of balanced panel data regression analysis. We treat the panel data as stacked, cross-sectional units, where units are respective countries. We use the fixed-effect model with heteroskedasticity corrected standard errors. The data on the variables used in this empirical work are taken from the World Bank Development Indicators (WDI, 2012) for the period 1996-2010. The definition and descriptive statistics for each variable used in the model are provided, respectively, in Tables 1 and 2.

Table 1: Variable Description and Source Information

\begin{tabular}{|c|c|}
\hline Variable & Description \\
\hline GDP & $\begin{array}{l}\text { Gross Domestic Product Per Capita, measured in constant } 2000 \text { US\$. Taken from } 2012 \text { World } \\
\text { Development Indicators dataset. }\end{array}$ \\
\hline REM & $\begin{array}{l}\text { Workers' Remittances and compensation of employees received (per capita), measured in current US } \\
\text { dollars. Taken from } 2012 \text { World Development Indicators dataset. }\end{array}$ \\
\hline FDI & $\begin{array}{l}\text { Foreign Direct Investment, net inflow (\% of GDP). Taken from } 2012 \text { World Development Indicators } \\
\text { dataset. }\end{array}$ \\
\hline GFC & $\begin{array}{l}\text { Gross Capital Formation, measured in constant } 2000 \text { US\$. We evaluated the Gross Capital Formation } \\
\text { input using the perpetual inventory method } K_{t}=(1-\delta) K_{t-1}+I_{t} \text {, where } I_{t} \text { is Gross Capital } \\
\text { Formation (in current } 2000 \text { US\$) and } \delta \text { is the depreciation rate }(0<\delta<1) \text { which is taken } \\
\delta=0.06\end{array}$ \\
\hline & $\begin{array}{l}\text { The initial capital stock is calculated by formula } K_{t}=\frac{I_{t}}{(g+\delta)} \text {, } \\
\text { where }(g) \text { is the average growth rate of the real output for the first ten years, 1996-2005. Data for this } \\
\text { variable are taken from } 2012 \text { World Development Indicators dataset. Used in the model per capita. }\end{array}$ \\
\hline TOT & $\begin{array}{l}\text { Trade Openness, measured as the value of total trade (imports plus exports) as a percentage of nominal } \\
\text { GDP. Data on exports, imports, and nominal GDP taken from } 2012 \text { World Development Indicators } \\
\text { dataset. }\end{array}$ \\
\hline
\end{tabular}

We develop the work on estimating parameters based on three assumptions. The first assumption is the situation where intercepts and slope coefficients are constant over units and time. For this case, we use the fixedeffect Model I. The second assumption is that the slope coefficients are constant and that the intercept varies over the groups of countries. For this case, we use the classification of the countries by World Bank (2012) as 1- high income countries and 2- upper-middle income countries. We use a dummy variable for interception by developing fixed-effect Model II. The third assumption is the situation where the intercepts and slope coefficients vary over the groups of countries. In this case, we elaborate the fixed-effect Model III.

Table 2: Summary Statistics

\begin{tabular}{|l|r|r|r|r|r|r|}
\hline \multicolumn{1}{|c|}{ Variable } & \multicolumn{1}{c|}{ Mean } & Median & Minimum & Maximum & Std. Dev. & C.V. \\
\hline GDPPC & $4,627.44$ & $4,540.78$ & 895.56 & $13,836.20$ & $2,783.74$ & 0.60 \\
\hline REM_PC & 137.90 & 120.45 & 0.71 & 479.17 & 120.57 & 0.87 \\
\hline FDI & 5.10 & 3.98 & -29.23 & 52.05 & 6.67 & 1.31 \\
\hline GCF_PC & $6,780.70$ & $4,768.09$ & 106.67 & $31,508.50$ & $6,252.79$ & 0.92 \\
\hline TOT & 104.49 & 103.77 & 45.13 & 174.82 & 30.08 & 0.29 \\
\hline
\end{tabular}

Notes: Data are reported annually from 1996-2010 for 12 Central and Eastern European countries. For our analysis, all data are transformed in natural logarithmic forms. 


\section{HYPOTHESES AND EMPIRICAL MODELS}

The main goal of the present study is to highlight the effect of remittances (REM) on economic growth (GDP). We will also analyze the effects of other traditional sources of economic growth, such as gross capital formation (GCF), foreign direct investment (FDI), and openness of the economy (TOT). For this purpose, the five following hypotheses are stated, tested, and commented as below.

H1: Because we are investigating the direct effect of remittances on growth, we expect the role of remittances to be negative. We believe that remittances in our sample countries are used mostly for consumption and to increase the standard of living for family in the home country rather than using it for profit-driven investments. This expectation is in line with the conclusion of Chami, Fullenkamp, and Jahjah (2005) and Barajas et al. (2009).

H2: We expect the effect of FDI on economic growth to be positive, because CEE countries, in developing their standard of living in line with Western European countries, have faced limitations on capital input. This situation increases the role of external capital flow in general and consequently the role of FDI as part of it. The expectation of this hypothesis (positive effect of FDI on growth) is in line with the results of other works such as Bende-Nabende and Ford (1998), Soysa and Oneal (1999), and Jasminka Sohinger (2005), which all concluded that FDI plays a positive role in economic growth.

H3: We expect a positive effect of gross capital formation per capita (GCF) on output growth. This can be understood simply, because the increase of fixed capital inputs increases the output produced. This is in line with the conclusions of Solow (1958), De Long and Summers (1991), De long, Summers, and Abel (1992), and Shujie Yao and Kailei Wei (2007), all of whom concluded that fixed capital is the key factor that promotes growth.

H4: We expect a positive impact on economic growth caused by the openness of the economy. This expectation is consistent with the results of Buthe and Milner (2008) who, after analyzing 122 developing countries concluded that joining trade agreements allowed developing countries to increase economic growth.

H5: In the present study, a structural break exists in the data according to the level of income achieved by the countries classified by the World Bank. We expect the effect of remittances on growth to be positive for the group of countries that have reached a high income level and negative for the group of countries with upper-middle income level.

We carry out the panel unit root test on the levels of the dependent and independent variables used in the models to test whether the variables are stationary. For this reason, we use the Im, Pesaran, and Shin (IPS) approach, which developed a panel unit root test for joint null hypothesis that all groups have a unit root. Based on the results (Table 3), we reject the null hypothesis at $1 \%$ in favor of a stationary relationship between the variables of interest. In other words, there is a long-run relationship between output and the independent variables used in the present study (REM, FDI, GCF, and TOT).

Table 3: Panel Unit Root Test on the Levels of Variables

\begin{tabular}{|l|c|}
\hline \multicolumn{1}{|c|}{ Variable } & IPS Statistics \\
\hline GDP & -2.36817 \\
\hline REM & -3.39558 \\
\hline FDI & -3.41418 \\
\hline GCF & -3.18542 \\
\hline TOT & -3.55281 \\
\hline
\end{tabular}

The variables in Table 3 are in natural logarithmic forms. The IPS tests Ho: all groups have a unit root. The critical values for $10 \%, 5 \%$, and $1 \%$ are $-1.89,-2.00$, and -2.22 , respectively. Based on the results, we can reject the unit root hypothesis at $1 \%$.

We use ANOVA and ANCOVA models, which contain both quantitative and qualitative variables (dummy). Table 4 includes the results from using the fixed-effect model on the panel data of 12 CEE countries for the period 1996-2010. The fixed-effect model is developed by considering three assumptions. In the first case, we 
use the fixed-effect model under the assumption that intercepts and the slope coefficients are constant over units and time. The model developed for this case is as follows:

$$
\ln g d p=\beta_{0}+\beta_{1} \ln r e m_{i t}+\beta_{2} \ln f d i_{i t}+\beta_{3} \ln g c f_{i t}+\beta_{4} \ln t o t_{i t}+\varepsilon_{i t}
$$

The estimated results in Table 4 under the Model I column show that REM and FDI have a negative and statistically significant effect on the GDP per capita (at $p<0.1$ ). Accordingly, we find that an increase in REM or FDI by $10 \%$ results in decreasing the output, respectively, by about $0.9 \%$ or $0.8 \%$. These results are in line with the conclusion achieved in the work of Chami, Fullenkamp, and Jahjah (2005) after they analyzed data on 113 countries. They found a negative effect of remittances on growth. The negative effect of FDI on growth is in line with the conclusions achieved by Yong (1993), Easterly (1993), Feldstein (2000), and Dong-Hyeon Kim, Shu-Chin Lin, and Yu-Bo Suen (2012). Estimated slope coefficients for gross capital formation and openness of economy to international trade show positive and statistically significant effects on GDP per capita, respectively, at $p<0.01$ and $p<0.1$. Thus, if we increase the gross capital formation or trade openness by $10 \%$, then the GDP per capita will increase respectively by about $5.2 \%$ and $1.8 \%$. The value $R^{2}=0.77$ shows that $77 \%$ of the variation in the output per capita is explained by the variation in the predictor variables used in Model 1.

With the results from Model 1, we have estimated the equation as follows:

$$
G D P=3.62-0.091 R E M-0.0845 F D I+0.517 G C F+0.178 T O T+\varepsilon
$$

\begin{tabular}{|c|c|c|c|}
\hline Variable & Model I & Model II & Model III \\
\hline Constant & $\begin{array}{l}3.62087 * * * \\
(0.374234) \\
\end{array}$ & $\begin{array}{l}4.88253 * * * \\
(0.236155) \\
\end{array}$ & $\begin{array}{l}5.15300 * * * \\
(0.311002) \\
\end{array}$ \\
\hline REM & $\begin{array}{l}-0.0909061 * * * \\
(0.0187800)\end{array}$ & $\begin{array}{l}-0.0442234 * * * \\
(0.0144091)\end{array}$ & $\begin{array}{l}0.0108753 \\
(0.0154819)\end{array}$ \\
\hline FDI & $\begin{array}{l}-0.0845064 * * * \\
(0.0239685)\end{array}$ & $\begin{array}{l}-0.0740782 \text { *** } \\
(0.0229581)\end{array}$ & $\begin{array}{l}-0.0727616^{* *} \\
(0.0359548) \\
\end{array}$ \\
\hline GCF & $\begin{array}{l}0.516702 * * * \\
(0.0259071)\end{array}$ & $\begin{array}{l}0.353579 * * * \\
(0.0318821) \\
\end{array}$ & $\begin{array}{l}0.308653 * * * \\
(0.0186509) \\
\end{array}$ \\
\hline TOT & $\begin{array}{l}0.177996^{*} \\
(0.0920500) \\
\end{array}$ & $\begin{array}{l}0.208939 * * * \\
(0.0595450) \\
\end{array}$ & $\begin{array}{l}0.185710 * * * \\
(0.0634375) \\
\end{array}$ \\
\hline Dummy & - & $\begin{array}{l}-0.511499 * * * \\
(0.0524401)\end{array}$ & $\begin{array}{l}-0.283493 * * * \\
(0.0666381)\end{array}$ \\
\hline d_REM & - & - & $\begin{array}{l}-0.0564021 * * \\
(0.0248691)\end{array}$ \\
\hline d_FDI & - & - & $\begin{array}{l}-0.141513 \text { *** } \\
(0.0523527)\end{array}$ \\
\hline d_GCF & - & - & $\begin{array}{l}0.00494579 \\
(0.0106717) \\
\end{array}$ \\
\hline d_TOT & - & - & $\begin{array}{l}0.00259624 * * * \\
(0.00127661)\end{array}$ \\
\hline Number of observation & 180 & 180 & 180 \\
\hline Number of countries & 12 & 12 & 12 \\
\hline R-squared & 0.772832 & 0.873997 & 0.889882 \\
\hline
\end{tabular}

Table 4: Summary of Econometrical Results - Dependent Variable 1_GDP

Notes: $* * *, * *$, and $*$ denote significance at $p<0.01, p<0.05$, and $p<0.1$ levels, respectively. The results on standard errors are in parenthesis. Model 1 presents the results of the fixed-effects model corrected for standard errors for all 12 CEE countries. Model 2 presents results by using Least Squares Dummy Variables for differential interception coefficient. Model 3 presents results of the LSDV for differential interception and slope coefficients between the two groups.

In the second scenario, we assume that the interception coefficient differs between the two groups of countries. Thus, besides the quantitative variables, we employ qualitative variables (dummy) to highlight the differences in the interception coefficient. For this case, the model is developed as follows: 
$\ln g d p=\beta_{0}+d u m+\beta_{1} \ln r e m_{i t}+\beta_{2} \ln f d i_{i t}+\beta_{3} \ln g c f_{i t}+\beta_{4} \ln t o t_{i t}+\varepsilon_{i t}$

Where, dum $=1$ for countries with upper-middle income level.

$=0$ otherwise or for countries that belong to the group with high income

The econometrical results highlighted from Model 2 show that REM and FDI have negative and statistically significant effects on GDP per capita (at $p<0.01$ ). Thus, an increase by $10 \%$ in REM or FDI will decrease the output per capita respectively by about $0.44 \%$ or $0.74 \%$. The estimated parameters for GCF and TOT show positive and statistically significant effects on growth (at $p<0.01$ ). Accordingly, an increase by $10 \%$ in the amount of capital or the volume of trade as a percentage of GDP will cause an increase in output by about $3.5 \%$ or $2.1 \%$ respectively. The interception coefficient for the group of countries with upper-middle income level is slightly lower than that of the group of countries with a high income level. For the group of countries with the high income level, the interception coefficient is about 4.88 , whereas for the other group of countries, the interception coefficient is about 4.37. Recall that the group of countries with high income level is used as the benchmark category. As in the first model, the value $R^{2} \approx 0.87$ is a good figure, which indicates that $87 \%$ of the variation in GDP per capita is explained by the variation in the predictor variables included in Model II. Based on the parameters estimated by Model II, we have estimated the equation as follows:

\section{$G D P=4.88-0.512 d u m-0.044 R E M-0.074 F D I+0.354 G C F+0.209 T O T+\varepsilon$}

In the third scenario, we assume that the interception coefficient and the slopes vary across the groups of countries. Thus, we use other qualitative variables to more specifically examine the role of each factor taken into consideration in both groups of countries. The model developed in this case is as follows:

$$
\begin{aligned}
\ln g d p= & \beta_{0}+d+\beta_{1} \ln r e m_{i t}+\beta_{2} \ln f d i_{i t}+\beta_{3} \ln g c f_{i t}+\beta_{4} \ln t o t_{i t} \\
& +\beta_{5} d \ln R E M_{i t}+\beta_{6} d \ln f d i_{i t}+\beta_{7} d \ln g c f_{i t}+\beta_{8} d \ln t o t_{i t}+\varepsilon_{i t}
\end{aligned}
$$

The results of the regression are given in Table 4 under the last column (Model III). In this case, we see that the value $R^{2} \approx 0.89$ is a good figure, which indicates that $89 \%$ of the variation in GDP per capita is explained by the variation in the predictor variables included in Model III. The estimated equation with the parameters found by using the econometrical Model III is as follows:

$$
\begin{aligned}
G D P= & 5.165-0.284_{-} d+0.0124 R E M-0.0488 F D I+0.3006 G C F-0.18991 T O T \\
& -0.0505 d_{-} R E M-0.1565 d_{-} F D I+0.0066 d_{-} F D I+0.0025 d_{-} T O T+\varepsilon
\end{aligned}
$$

The estimated coefficient $\left(\beta_{1} \approx 0.011\right)$ shows that remittances have a positive but not statistically significant effect on growth in countries that now belong to the high-income group. The estimated coefficient $\left(\beta_{5}=0.011-0.056=-0.045\right)$ shows that remittances have a negative and statistically significant effect (at $p<0.05$ ) on output in countries with upper-middle income level. Accordingly, an increase by $10 \%$ in the amount of remittances will increase the output by about $0.11 \%$ in countries with high income and will decrease the output by about $0.45 \%$ in the group of countries with upper-middle income level.

The estimated coefficients, $\beta_{2}$ and $\beta_{6}$, show that the role of FDI on growth in both groups of countries is negative and statistical significant at $p<0.05$ and $p<0.01$, respectively. Accordingly, an increase of FDI by $10 \%$ will decrease output by about $0.7 \%$ in group of countries with high income and $2.2 \%$ in the group of countries with upper-middle income level. The positive effects of GCF and TOT on output are slightly more in countries with upper-middle income level. Estimated coefficients are positive and statistically significant (at $p<0.01)$ except the case of GCF in countries that belong to the group with upper-middle income, which is not statistically significant. 
Consequently, an increase by $10 \%$ in the volume of trade as percentage to the GDP will effect growth respectively by about $1.86 \%$ in countries with high income and by about $1.87 \%$ in countries with upper-middle income level.

\section{CONCLUSIONS}

The present study has investigated the role of remittances on output per capita experienced by twelve CEE countries over the period of time 1996-2010 from the empirical point of view. The role of remittances on growth is also analyzed by using a structure break in the data due to the level of income achieved by countries, by separating countries of interest in two groups based on the World Bank classification (World Bank, 2012). The present study is developed in contrast with the role of other explanatory variables such as foreign direct investment, gross capital formation, and economic openness.

The results show that workers' remittances received by countries under investigation have a negative effect on GDP per capita. We have highlighted that increasing remittances by $10 \%$ will decrease the level of GDP per capita by about $0.9 \%$. Another interesting conclusion is the effect of remittances on GDP per capita in both groups of countries when we use the dummy variable. The effect of remittances on growth is positive, but statistically insignificant, in the group of countries that are now classified by the World Bank (2012) as countries with a high income level. Accordingly, an increase in remittances by $10 \%$ will increase the GDP per capita by about $0.11 \%$. This conclusion is in line with Hypothesis 1. For countries classified in the upper-middle income level group, an increase by $10 \%$ in REM decreases the GDP per capita by about $0.45 \%$. This result is in line with the conclusions achieved by Chami, Fullenkamp, and Jahjah (2005) who concluded that remittances have a negative effect on growth. One reason the role of remittances on growth in the second group of countries is negative may be caused by the remittances received by these countries being used mainly for immediate consumption rather than investing; so an important topic for future work will be to analyze the indirect role of remittances on growth experienced in these countries.

Another interesting conclusion of our work is the negative effect of FDI on growth experienced by CEE countries of interest. Accordingly, an increase of the FDI by $10 \%$ reduces output by about $0.85 \%$. When we use the dummy variable to measure the role of remittances on growth for each group (Model III), we find that the negative effect of FDI on growth is more pronounced in the second group of countries compared to the first group. Thus, an increase in FDI by $10 \%$ will decrease output by about $2.1 \%$ in the first group of countries, whereas the decreasing effect in the second group of countries is about $0.7 \%$. The negative effect of FDI on growth could be the case when the FDI crowds out domestic investment in new technology by accelerating the old, disused technology (Young, 1993). Another reason that FDI can have a negative effect on growth could be preferential policies (tax treatment, etc.) for foreign capital used by governments to increase the inflow of FDI. This could create distortion between foreign and domestic capital (Easterly, 1993).

The empirical results show that the role of physical capital and the openness of an economy on growth is positive and statistically significant (at $p<0.01$ and $p<0.1$ ). Accordingly, an increase in the amount of physical capital or the volume of trade by $10 \%$ will increase the output respectively by about $5.2 \%$ and $1.8 \%$. The role of GCF and TOT on growth, when we use the structure break according to the level of income achieved by countries, is slightly more positive in countries with upper-middle income level than in those with a high income level.

Important policy implication can be drawn from these results. CEE countries must consider reforms for making the use of remittances received more efficient towards growth. These reforms are more necessary for the group of countries with the upper-middle income level. Also, reforms are necessary for increasing the role of FDI on growth, this maybe by considering fiscal policies used to attract foreign capital inward. 


\section{AUTHOR INFORMATION}

Altin Gjini, Ph.D. candidate, is an instructor of economics and finance at State University "Aleksander Moisiu" Durres, Albania and is in the final stage of his doctoral program at the same university. He works full-time at the Albanian General Directory of Customs, Ministry of Finance. His main research is focused on macroeconomic policies with respect to growth, investment, consumption, VAT, and so on. E-mail: altin_gjini@yahoo.com

\section{REFERENCES}

1 Bende-Nabende \& Ford, J. L, (1998), FDI, policy adjustment and endogenous growth: Multiplier effects from a small dynamic model for Taiwan 1959-1995, World Development, Vol. 26(7): 1315-1330.

2 Barajas, A. R., Chami, C., Fullenkamp, M., Gapen, \& Montiel, P. (2009), Do workers' remittances promote economic growth? Working Paper, No. WP/09/153, Washington DC: International Monetary Fund.

3 Bhaskara Rao, B. \& Gazi Mainul Hassan, (2012), Are the direct and indirect growth effects of remittances significant? The world Economy, 35(3): 351-372.

4 Gabriela Mundaca, B. (2009), Remittances, Financial market development, and economic growth: The case of Latin America and the Caribbean, Review of Development Economics, Vol. 13, Issue 2, pp 288-303.

$5 \quad$ Bichaka Fayissa \& Christian Nsiah, (2010), The impact of remittances on economic growth and development in Africa, The American Economist, Vol.55, No.2, pp: 92-103.

6 Chami R., C. Fullenkamp, \& Jahjah, S. (2005). Are immigrant remittance flows a source of capital for development?, IMF Staff Papers, 52(1): 55-81.

7 Dong-Hyeon Kim, Shu-Chin Lin, \& Yu-Bo Suen, (2012), Dynamic effects of financial openness on economic growth and macroeconomic uncertainty, Emerging Markets Finance \& Trader, Vol. 48, No.1, pp: 25-54.

8 Eduard F. Denison, (1980). The contribution of capital to economic growth, The American Economic Review, Vol.70, No. 2, pp: 220-224.

9 Easterly W, (1993), How much do distortions affect growth? Journal of Monetary Economics 32, no 2, pp: $187-212$.

10 Fassman \& Munz, (1994), European east-west migration, International Migration Review, 28: 520-538

11 Feldstein M. (2000). Aspects of global economic integration: Outlook for the future, Working Paper No.78999, Cambridge, MA: National Bureau of Economic Research.

12 Gerald W. Scully, (2002), Economic freedom, government policy and trade-off between equity and economic growth, Public Choice, Vol. 113, No. 1/2, pp 77-96.

13 Giuliano P \& Marta Ruiz-Arranz (2009), Remittances, financial development, and growth, Journal Development Economics, Vol. 90, Issue. 1, pp: 144-152.

14 Indra de Soysa, John R. Oneal, (1999), Boon or Bane? Reassessing the productivity of FDI, American Sociological Review, Vol.64, No.5, pp: 766-782.

15 Ismet Koc \& Isil Onan, (2004), International immigrants' remittances and welfare status of left-behind families in Turkey, International Migration Review, Vol. 38, No. 1, pp: 78-112.

16 Jasminka Sohinger, (2005), Growth and convergence in the European transition economies: The impact of foreign direct investment, Eastern European Economics, Vol. 43, No.2, pp 73-94.

17 J. Bradford De Long \& Laurence H. Summers, (1991), Equipment investment and economic growth, The Quarterly Journal of Economics, Vol. 106, No. 2, pp. 445-502.

18 J. Bradford De Long, Laurence H. Summers, \& Andrew B. Abel, (1992), Equipment investment and economic growth: How strong is the nexus, Brooking Papers on Economic Activity, Vol. 1992, No. 2, pp. $157-211$.

19 Matteo Bugamelli \& Francesco Paterno, (2011), Output growth volatility and remittances, Economica, Vol. 78, Issue 311, pp 480-500.

20 Miguel Leon_Ledesma \& Matloob Piracha, (2004), International migration and the role of remittances in Eastern Europe, International Migration, Vol. 42, Issue 4, pp65-83.

21 Romer, P. (1986), Increasing returns and long-run growth, Journal of Political Economy, 94, pp 500-521.

22 Robert J. Barro, (1991), Economic growth in a cross section of countries, The Quarterly Journal of

Economics, Vol. 106, No. 2, pp 407-443. 
23 Robert M. Solow, (1956), A contribution to the theory of economic growth, Quarterly Journal of Economics, 70, pp 65-94.

24 Robert M. Solow, (1957), Technical change and the aggregate production function, The Review of Economics and Statistic, Vol. 39, No. 3, pp. 312-320.

25 Russell Sharon Stonton, (1992), Migrant remittances and development, International Migration Quarterly Review, 30 (3/4), pp. 267-87.

26 Shujie Yao \& Kailei Way, (2007), Economic growth in the presence of FDI: The Perspective of Newly Industrializing Economies, Journal of Comparative Economics, 35, pp 211-234.

27 Taylor J. E. (1992), Remittances and inequality reconsidered: Direct, indirect and inter-temporal effects, Journal of Policy Modeling, Vol. 12, 2, pp. 187-208.

28 Tim Buthe \& Helen V. Miller, (2008), The FDI into developing countries: Increasing FDI through international trade agreement, Midwest Political Science Association, Vol. 52, No. 4, pp. 741-762.

29 Wenbo Wu \& Otto A. Davis, (1999), The two freedoms, economic growth and development: An empirical study, Public Choice, Vol. 100, No. 1/2, pp 39-64.

30 World Bank, (2011), Migrants and remittances, Fact Book $2011\left(2^{\text {nd }}\right.$ Ed), Available at http://siteresources.worldbank.org/INTLAC/Resources/Factbook2011-Ebook.pdf

31 World Bank, (2012), Available at http://databank.worldbank.org/ddp/viewclassifications?HIERARCHY=classificationDINENTION=WDI C try, accessed April 2012.

31 Young A. (1993), Substitution and complementary in endogenous innovation, Quarterly Journal of Economics, 108, no 3, pp 775-807. 


\section{NOTES}

